\title{
Magnetic properties of $\mathrm{Ce}_{1.5} M^{\prime}{ }_{0.5} \mathrm{Ge}_{4} \mathrm{O}_{12}(M=\mathrm{Mn}$, $\left.\mathrm{Co} ; M^{\prime}=\mathrm{Ni}, \mathrm{Cu}\right)$
}

Diming $\mathrm{Xu}^{1}$, Maxim Avdeev ${ }^{2,3}$ and Peter D. Battle ${ }^{1, *}$

1. Inorganic Chemistry Laboratory, Oxford University, South Parks Road, Oxford, OX1 3QR, U. K.

2. Australian Nuclear Science and Technology Organisation, Lucas Heights, NSW 2234, Australia

3. School of Chemistry, The University of Sydney, Sydney, NSW 2006, Australia

Keywords: neutron diffraction; antiferromagnet; metamagnet

* to whom correspondence should be addressed: peter.battle@chem.ox.ac.uk 


\begin{abstract}
A study of the solid solutions $\mathrm{Ce}_{2-\mathrm{x}} M^{\prime}{ }_{x} \mathrm{Ge}_{4} \mathrm{O}_{12}\left(M=\mathrm{Mn}, \mathrm{Co} ; M^{\prime}=\mathrm{Ni}, \mathrm{Cu}\right)$ by $\mathrm{X}$-ray diffraction and magnetometry is described. For $M=$ Co the introduction of $\mathrm{Ni}$ and $\mathrm{Cu}$ was possible for $x \leq 0.5$; for $M=\mathrm{Mn}$ attempts to introduce $\mathrm{Cu}$ were unsuccessful but $\mathrm{CeMn}_{1.5} \mathrm{Ni}_{0.5} \mathrm{GeO}_{4}$ was obtained as a single phase. These compositions crystallise in the space group $P 4 / n b m$ with $a \sim 9.76, c \sim 4.85 \AA$. They all order antiferromagnetically with $\mathrm{T}_{\mathrm{N}}<10 \mathrm{~K}$. The magnetic structures adopted by $\mathrm{CeMn}_{1.5} \mathrm{Ni}_{1.5} \mathrm{Ge}_{4} \mathrm{O}_{12}$ and $\mathrm{CeCo}_{1.5} \mathrm{Cu}_{0.5} \mathrm{Ge}_{4} \mathrm{O}_{12}$ were shown by neutron diffraction to be the same as those adopted by $\mathrm{CeMn}_{2} \mathrm{Ge}_{4} \mathrm{O}_{12}$ and $\mathrm{CeCo}_{2} \mathrm{Ge}_{4} \mathrm{O}_{12}$, respectively. The in-field metamagnetic transition of the latter to a weakly ferromagnetic phase was shown to persist in the $\mathrm{Cu}$-doped composition. The available data suggest that the anisotropy associated with the $\mathrm{Co}^{2+}$ cation plays a dominant role in determining the magnetic behaviour of these compounds.
\end{abstract}

\title{
Introduction
}

We have previously[1] reported a study of the magnetic properties of $\mathrm{CeMn}_{2-\mathrm{x}} \mathrm{Co}_{\mathrm{x}} \mathrm{Ge}_{4} \mathrm{O}_{12}$, a solid solution containing $\mathrm{Ce}^{4+}, \mathrm{Mn}^{2+}$ and $\mathrm{Co}^{2+}$ cations that crystallizes in the tetragonal crystal structure shown in Figure 1. The $d$ - and $f$-block cations lie in sheets perpendicular to [001] and occupy the $4 f$ and $2 b$ sites, respectively, of the space group P4/nbm. These sheets are separated by layers of $\mathrm{Ge}_{4} \mathrm{O}_{12}$ groups, each group being formed from four vertex-sharing $\mathrm{GeO}_{4}$ tetrahedra. This arrangement of anions results in the $4 f$ and $2 b$ sites being coordinated by six oxide ions at the vertices of an elongated octahedron and eight oxide ions at the vertices of a square antiprism, respectively.

The magnetic properties of $\mathrm{CeMn}_{2-\mathrm{x}} \mathrm{Co}_{\mathrm{x}} \mathrm{Ge}_{4} \mathrm{O}_{12}$ change markedly with composition. Below 7.6 $\mathrm{K}$ the magnetic moments of the $\mathrm{Mn}^{2+}$ cations in $\mathrm{CeMn}_{2} \mathrm{Ge}_{4} \mathrm{O}_{12}$ align along [001] in the antiferromagnetic arrangement shown[2] in Figure 2. Nearest-neighbour (NN) magnetic cations within each (001) layer couple antiferromagnetically but the coupling to NN cations in the neighbouring (001) sheets is ferromagnetic; the structural and magnetic unit cells are therefore the same size. As a result of the relative size of the unit cell parameters of this structure, that is $a \sim 9.8 \AA, c \sim 4.9 \AA$ and hence $a \sim 2 c$, the $d$-block cations in this structure can be considered to form a simple cubic array with a unit-cell parameter of $\sim 4.9 \AA$ and the magnetic structure shown in Figure 2 can be therefore be described as C-type in the notation of Wollan and Koehler[3]. $\mathrm{CeCo}_{2} \mathrm{Ge}_{4} \mathrm{O}_{12}$ is also antiferromagnetic at low temperatures, but the spin arrangement in the antiferromagnetic phase is not as simple as that seen in 
$\mathrm{CeMn}_{2} \mathrm{Ge}_{4} \mathrm{O}_{12}$. The unit cell doubles in size along [001] and the spins no longer align in a collinear manner, see Figure 3. The [100] spin components adopt a G-type arrangement in which they couple antiparallel to their six NN cations, whereas the [010] components align ferromagnetically in each (001) sheet with neighbouring sheets being antiferromagnetically coupled, that is they adopt an A-type arrangement; there is no spin component along [001]. The adoption of different magnetic structures shows that the relative strengths of the NN and next-nearest-neighbour (NNN) interactions are different in the two compounds and the rotation of the spins from [001] in $\mathrm{CeMn}_{2} \mathrm{Ge}_{4} \mathrm{O}_{12}$ to a direction within the (001) sheets in $\mathrm{CeCo}_{2} \mathrm{Ge}_{4} \mathrm{O}_{12}$ suggests that the single-ion anisotropy associated with $\mathrm{Co}^{2+}$ also influences the magnetic structure. This is consistent with the results of a study of $\mathrm{CeMn}_{1.5} \mathrm{Co}_{0.5} \mathrm{Ge}_{4} \mathrm{O}_{12}$ which showed that although the C-type structure of $\mathrm{CeMn}_{2} \mathrm{Ge}_{4} \mathrm{O}_{12}$ is retained, the substitution of $\mathrm{Co}^{2+}$ for $25 \%$ of the $\mathrm{Mn}^{2+}$ cations causes the ordered spins to rotate into the (001) sheets. The composition dependence of the magnetic behaviour is further emphasised when the system is studied by neutron diffraction in the presence of an external magnetic field. The antiferromagnetic structure of $\mathrm{CeMn}_{2} \mathrm{Ge}_{4} \mathrm{O}_{12}$ does not change in a field of $30 \mathrm{kOe}$ but the unit-cell doubling seen in $\mathrm{CeCo}_{2} \mathrm{Ge}_{4} \mathrm{O}_{12}$ in zero field is lost in a metamagnetic transition that results in C-type and B-type ordering of the [100] and [010] spin components, respectively, see Figure 4. We have subsequently shown that changing the tetravalent cation also changes the magnetic behaviour[4]. $\mathrm{ZrMn}_{2} \mathrm{GeO}_{4}$ has the same magnetic structure as $\mathrm{CeMn}_{2} \mathrm{Ge}_{4} \mathrm{O}_{12}$ but the spin-ordering pattern adopted by $\mathrm{ZrCo}_{2} \mathrm{Ge}_{4} \mathrm{O}_{12}$ in the absence of an applied field is the same as that adopted by $\mathrm{CeCo}_{2} \mathrm{Ge}_{4} \mathrm{O}_{12}$ in a field of $30 \mathrm{kOe}$. This change in magnetic structure presumably stems from the subtle changes in the crystal structure that occur because of the difference in the ionic radii of $\mathrm{Ce}^{4+}$ and $\mathrm{Zr}^{4+}$.

Prompted by the apparent sensitivity of the magnetic properties of these germanates to chemical composition we have now expanded our study by introducing two more magnetic cations, $\mathrm{Ni}^{2+}$ and $\mathrm{Cu}^{2+}$ into the structure. We describe below the results of our investigation of the solid solutions $\mathrm{Ce}_{2-\mathrm{x}} M^{\prime}{ }_{x} \mathrm{Ge}_{4} \mathrm{O}_{12}\left(M=\mathrm{Mn}, \mathrm{Co} ; M^{\prime}=\mathrm{Ni}, \mathrm{Cu}\right)$.

\section{Experimental}

We attempted to prepare polycrystalline samples of $\mathrm{Ce}_{2-\mathrm{x}} M^{\prime}{ }_{x} \mathrm{Ge}_{4} \mathrm{O}_{12}\left(M=\mathrm{Mn}, \mathrm{Co} ; M^{\prime}=\mathrm{Ni}\right.$, $\mathrm{Cu}$ ) in solid-state reactions. The appropriate stoichiometric quantities of $\mathrm{CeO}_{2}, \mathrm{MnCO}_{3}$, $\mathrm{Co}_{3} \mathrm{O}_{4}, \mathrm{NiO}, \mathrm{CuO}$ and $\mathrm{GeO}_{2}$ were mixed thoroughly using an agate mortar and pestle. A $10 \%$ excess of $\mathrm{GeO}_{2}$ was added in the case of the copper-free compounds to counteract its loss at 
high temperature[5]. The copper-free mixtures were heated at $1075{ }^{\circ} \mathrm{C}$ for 4 days with intermediate cooling and regrinding every two days. They were then pressed into pellets and annealed at the same temperature for another 10 days with cooling and regrinding every two days. Further heating at $1100{ }^{\circ} \mathrm{C}$ for 1 day was carried out if $\mathrm{GeO}_{2}$ was detected as an impurity phase. The copper-containing mixtures were synthesized using the same method but at $1050{ }^{\circ} \mathrm{C}$ to avoid melting.

$\mathrm{X}$-ray powder diffraction (XRPD) patterns were recorded at room temperature using $\mathrm{Cu} \mathrm{K} \alpha_{1}$ radiation. Neutron powder diffraction (NPD) patterns were collected from selected compositions using the diffractometer ECHIDNA at ANSTO. Wavelengths of $1.622 \AA$ and $2.4395 \AA$ were used to collect data at selected temperatures in the range $1.6 \leq \mathrm{T} / \mathrm{K} \leq 300$ with the samples contained in vanadium cans. In one case, additional data were collected at $1.6 \mathrm{~K}$ over the magnetic field range $0 \leq \mathrm{H} / \mathrm{kOe} \leq 30$. When data were to be collected in an applied field the sample was pressed into relatively large pieces to prevent movement in the field, otherwise loose powders were used. The data were analysed by the Rietveld method[6] using the program GSAS[7] and the peak function developed by van Laar and Yelon[8]. Regions of the diffraction profile contaminated by scattering from the cryomagnet were excluded from the subsequent data analysis.

Magnetic measurements were performed using both Quantum Design MPMS XL and MPMS 5 SQUID magnetometers. DC susceptibility measurements were made over the temperature range $2 \leq \mathrm{T} / \mathrm{K} \leq 300$ in an applied field of 100 Oe after both zero-field cooling (ZFC) and field cooling (FC) of the samples. The field dependence of the magnetization was measured at $2 \mathrm{~K}$ over the field range $-50 \leq \mathrm{H} / \mathrm{kOe} \leq 50$ after the samples had been cooled in a magnetic field of $50 \mathrm{kOe}$.

\section{Results}

XRPD suggested that our syntheses had produced single-phase, tetragonal reaction products of $\mathrm{CeCo}_{1.5} \mathrm{Ni}_{0.5} \mathrm{Ge}_{4} \mathrm{O}_{12}, \mathrm{CeCo}_{1.5} \mathrm{Cu}_{0.5} \mathrm{Ge}_{4} \mathrm{O}_{12}$ and $\mathrm{CeMn}_{1.5} \mathrm{Ni}_{0.5} \mathrm{Ge}_{4} \mathrm{O}_{12}$. All the reaction products containing higher concentrations of $\mathrm{Ni}^{2+}$ or $\mathrm{Cu}^{2+}$ were impure. In the case of $\mathrm{CeMn}_{1.5} \mathrm{Cu}_{0.5} \mathrm{Ge}_{4} \mathrm{O}_{12}$ the Bragg peaks associated with the target compound dominated the diffraction pattern but peaks indicative of $\mathrm{CuGeO}_{3}[9]$ impurity phase were also present. The cobalt-containing products were green in colour whereas those containing manganese were brown. The tetragonal phase in each of the XRPD patterns could be indexed in the space group P4/nbm (No. 125); unit cell parameters are listed in Table 1. Rietveld analysis of the 
data allowed the concentration of $\mathrm{CuGeO}_{3}$ in $\mathrm{CeMn}_{1.5} \mathrm{Cu}_{0.5} \mathrm{Ge}_{4} \mathrm{O}_{12}$ to be quantified as 6.7(4) $\mathrm{wt} \%$. This composition will not be discussed further.

The temperature dependence of the dc molar susceptibility and the field dependence of the magnetisation at $2 \mathrm{~K}$ are shown in Figure 5 for the three remaining, tetragonal phases. The Curie constant, $C$, and the Weiss temperature, $\theta$, resulting from fitting the Curie-Weiss law to the FC data collected above $\mathrm{T}=150 \mathrm{~K}$ are listed in Table 2 . The table also includes a value for the effective magnetic moment, $\mu_{\text {eff }}$, of $M^{\prime}$. This was calculated assuming that $\mathrm{Co}^{2+}$ and $\mathrm{Mn}^{2+}$ behave as they do in $\mathrm{CeCo}_{2} \mathrm{Ge}_{4} \mathrm{O}_{12}$ and $\mathrm{CeMn}_{2} \mathrm{Ge}_{4} \mathrm{O}_{12}$, respectively.

On the basis of the $\mathrm{X}$-ray and magnetometry data, $\mathrm{CeMn}_{1.5} \mathrm{Ni}_{0.5} \mathrm{Ge}_{4} \mathrm{O}_{12}$ and $\mathrm{CeCo}_{1.5} \mathrm{Cu}_{0.5} \mathrm{Ge}_{4} \mathrm{O}_{12}$ were selected for further study by neutron diffraction Data were collected on $\mathrm{CeMn}_{1.5} \mathrm{Ni}_{0.5} \mathrm{Ge}_{4} \mathrm{O}_{12}$ at room temperature using a wavelength $\lambda=1.622 \AA$ and at 1.6 K using two wavelengths, $\lambda=1.622$ and $2.4395 \AA$. Additional Bragg peaks were visible at low angles in the data collected at the latter temperature, which is below that of the susceptibility maximum apparent in Figure 5. In order to account for these peaks in our Rietveld analysis it was necessary to assume that, at low temperatures, $\mathrm{CeMn}_{1.5} \mathrm{Ni}_{0.5} \mathrm{Ge}_{4} \mathrm{O}_{12}$ adopts the same antiferromagnetic structure as $\mathrm{CeMn}_{2} \mathrm{Ge}_{4} \mathrm{O}_{12}$, see Figure 2. This magnetic structure can be described in the magnetic space group $P 4^{\prime} / n b m$ ' (No. 125.5.1035)[10]. The fits to the NPD patterns collected using $\lambda=1.622 \AA$ are shown in Figure 6. The structural parameters derived from the refinements are listed in Table 3 and some selected bond lengths and bond angles are listed in Table 4. During the analysis of the NPD pattern collected using $\lambda=2.4395 \AA$ the structural parameters were constrained to the values derived from the data collected using $\lambda=1.622$. Analysis of the long-wavelength data resulted in a value of 3.70(2) $\mu_{\mathrm{B}}$ for the mean ordered moment at the $4 f$ site, which contains $\mathrm{Mn}^{2+}$ and $\mathrm{Ni}^{2+}$ in a ratio of $3: 1$ and thus has a theoretical, spin-only moment of $4.25 \mu_{\mathrm{B}}$.

Neutron diffraction data were collected on $\mathrm{CeCo}_{1.5} \mathrm{Cu}_{0.5} \mathrm{Ge}_{4} \mathrm{O}_{12}$ at room temperature with $\lambda=$ $1.622 \AA$ and at $20 \mathrm{~K}$ and $1.6 \mathrm{~K}$ with $\lambda=2.4395 \AA$. Data were collected in magnetic fields of up to $30 \mathrm{kOe}$ at the lowest temperature. The data collected at $20 \mathrm{~K}$ were used to check for the presence in the sample of $\mathrm{CoGeO}_{3}$, which was present in the samples of $A \mathrm{Co}_{2} \mathrm{Ge}_{4} \mathrm{O}_{12}(A=$ $\mathrm{Ce}, \mathrm{Zr}$ ) studied previously. At room temperature the Bragg peaks in both the X-ray and neutron diffraction patterns of $\mathrm{CoGeO}_{3}$ are relatively weak and so they are easily overlooked when it is present as a low-level impurity. The most obvious sign of the presence of this phase is a strong magnetic Bragg peak that appears below the Néel temperature of $33 \mathrm{~K}[11]$. Data collected at $20 \mathrm{~K}$, which is above the magnetic transition temperature of 
$\mathrm{CeCo}_{1.5} \mathrm{Cu}_{0.5} \mathrm{Ge}_{4} \mathrm{O}_{12}$, can thus be used to quantify the concentration of $\mathrm{CoGeO}_{3}$ in a sample. In the present case it was found to be 2.0(1) wt \% and due allowance was made for this in our subsequent data analysis. The neutron diffraction pattern collected from $\mathrm{CeCo}_{1.5} \mathrm{Cu}_{0.5} \mathrm{Ge}_{4} \mathrm{O}_{12}$ at room temperature was consistent with the X-ray diffraction pattern and the structure could be refined in the space group $P 4 / \mathrm{nbm}$, see Figure 7 and Tables 5 and 6 . However, at $1.6 \mathrm{~K}$ additional peaks were observed that could be accounted for using the magnetic structure adopted in the absence of a field by $\mathrm{CeCo}_{2} \mathrm{Ge}_{4} \mathrm{O}_{12}$, see Figure 3. This structure has the magnetic space group $P_{2 c} b$ 'an (No. 50.9.385). The distribution of intensity across the magnetic Bragg peaks changed markedly when a magnetic field was applied. Diffraction patterns collected in fields of 5 and $10 \mathrm{kOe}$ revealed the coexistence of the structure drawn in Figure 3 and the weakly-ferromagnetic structure shown in Figure 4; only the latter was present in a field of $30 \mathrm{kOe}$. The high-field structure is the same as that adopted in high fields by $\mathrm{CeCo}_{2} \mathrm{Ge}_{4} \mathrm{O}_{12}$ and can be described in the magnetic space group $P b^{\prime}$ 'an', No. 50.6.382. The field-dependence of the neutron diffraction pattern is illustrated in Figure 8. In fields of 5 and $10 \mathrm{kOe}$ the low- and high-field magnetic phases were present in the ratios 66:34 and 30:70, respectively. The application of a magnetic field caused no significant changes to either the unit cell parameters or the atomic coordinates. The components of the ordered magnetic moment in $0 \mathrm{kOe}$ and $30 \mathrm{kOe}$ are presented in Table 7 along with their resultant. The moments do not align along a unit cell axis in either case and when $\mathrm{H}=0 \mathrm{kOe}$ they do not appear to pick out one of the principal axes of the octahedron. However, when $\mathrm{H}=30$ kOe the spins lie approximately perpendicular $\left(87^{\circ}\right)$ to the $\mathrm{Co} / \mathrm{Cu}-\mathrm{O} 1$ bond.

\section{Discussion}

Clearly, the six-coordinate sites in $\mathrm{CeMn}_{2} \mathrm{Ge}_{4} \mathrm{O}_{12}$ and $\mathrm{CeCo}_{2} \mathrm{Ge}_{4} \mathrm{O}_{12}$ can tolerate only a low level of $\mathrm{Ni}^{2+}$ or $\mathrm{Cu}^{2+}$ substituents. We attribute this to the relatively small size of these cations and the rigidity of the structural framework. The mean $\mathrm{Mn}-\mathrm{O}$ bond length in $\mathrm{CeMn}_{2} \mathrm{Ge}_{4} \mathrm{O}_{12}$ is $2.234 \AA$ [1], comparable to the value of $2.223 \AA$ found in MnO but considerably larger than the value of $2.086 \AA$ found in $\mathrm{NiO}[12]$. $\mathrm{A} \mathrm{Ni}^{2+}$ cation substituted onto the $4 f$ site in $\mathrm{CeMn}_{2} \mathrm{Ge}_{4} \mathrm{O}_{12}$ would therefore be underbonded if the structure was unable to respond to the presence of the substituent. Similar arguments can be made regarding the substitution of $\mathrm{Ni}^{2+}$ into $\mathrm{CeCo}_{2} \mathrm{Ge}_{4} \mathrm{O}_{12}$ where the mean $\mathrm{Co}-\mathrm{O}$ bond length is $2.169 \AA$. The bonds around the $4 f$ sites in $\mathrm{CeMn}_{1.5} \mathrm{Ni}_{0.5} \mathrm{Ge}_{4} \mathrm{O}_{12}$ are indeed shorter than those in $\mathrm{CeMn}_{2} \mathrm{Ge}_{4} \mathrm{O}_{12}$, having a mean length of $2.209 \AA$, but the $\mathrm{Ce}-\mathrm{O}$ and $\mathrm{Ge}-\mathrm{O}$ distances are essentially unchanged, despite a 
reduction in the unit cell parameters. We suggest that the relatively rigid bonding requirements of the $\mathrm{Ce}^{4+}$ cations and the $\mathrm{Ge}_{4} \mathrm{O}_{12}$ groups that make up the framework of the structure limit its flexibility in such a way that only a low concentration of $\mathrm{Ni}^{2+}$ cations can be tolerated. The $\mathrm{Cu}^{2+}$ cation is smaller than $\mathrm{Ni}^{2+}$, the mean $\mathrm{Cu}-\mathrm{O}$ distance in $\mathrm{La}_{2} \mathrm{CuO}_{4}$ being $2.073 \AA$ [13], and similar arguments can be used to explain the low tolerance of the parent compositions towards $\mathrm{Cu}^{2+}$ substitution. The greatest size mismatch between the $d$ block cations used in this work occurs between $\mathrm{Mn}^{2+}$ and $\mathrm{Cu}^{2+}$, consistent with the presence of significant level of impurity in our sample of $\mathrm{CeMn}_{1.5} \mathrm{Cu}_{0.5} \mathrm{Ge}_{4} \mathrm{O}_{12}$. The degenerate electronic ground state of $\mathrm{Cu}^{2+}$ favours a distorted, pseudo-tetragonal coordination environment which these germanates do offer, see Tables 4 and 6. However, the introduction of the Jahn-Teller ion onto the $4 f$ site in $\mathrm{CeCo}_{2} \mathrm{Ge}_{4} \mathrm{O}_{12}$ increases the ratio of the axial to equatorial bond lengths in the octahedron, that is $(4 f-\mathrm{O} 1) /(4 f-\mathrm{O} 2)$, only from $1.149(3)$ to 1.154(3), presumably because of the rigidity of the surrounding framework.. Finally we suggest that the relatively large difference between the $\mathrm{Co}-\mathrm{O}$ bond length in $\mathrm{CeCo}_{2} \mathrm{Ge}_{4} \mathrm{O}_{12}$ and that of $2.1315 \AA$ in $\mathrm{CoO}[12]$ is an indication that the framework cannot fully adapt to the coordination requirements of $\mathrm{Co}^{2+}$ and is consistent with the observation that $\mathrm{Co}^{2+}$ is the smallest cation that can fully occupy the $4 f$ site in this structure when the $2 b$ site is occupied by $\mathrm{Ce}^{4+}$.

The magnetometry data presented in Table 2 and Figure 5 show that at temperatures above $150 \mathrm{~K}$ the three compounds under discussion obey the Curie-Weiss law, with the dominant intercation interaction being antiferromagnetic in each case. If we assume that the paramagnetic $\mathrm{Mn}^{2+}$ and $\mathrm{Co}^{2+}$ cations behave as they do in $\mathrm{CeMn}_{2} \mathrm{Ge}_{4} \mathrm{O}_{12}$ and $\mathrm{CeCo}_{2} \mathrm{Ge}_{4} \mathrm{O}_{12}$, then the effective magnetic moments of $\mathrm{Ni}^{2+}$ and $\mathrm{Cu}^{2+}$ derived from the data are close to their spin-only values of 2.83 and $1.73 \mu_{\mathrm{B}}$, respectively. The susceptibility of $\mathrm{CeMn}_{1.5} \mathrm{Ni}_{0.5} \mathrm{Ge}_{4} \mathrm{O}_{12}$ shows that a phase transition occurs at $7.0 \mathrm{~K}$. The presence of both a susceptibility maximum and a difference in the ZFC and FC values below the maximum is consistent with a transition from a paramagnet to a weak ferromagnet, that is a canted antiferromagnet. The variation of the magnetisation with applied field shows weak hysteresis in low fields, further evidence that the low-temperature phase is not a simple antiferromagnet. However, any ferromagnetic component in the ordered spin structure was too weak to be detected in our neutron diffraction experiment and we were able to account for the data using the antiferromagnetic structure seen previously in $\mathrm{CeMn}_{2} \mathrm{Ge}_{4} \mathrm{O}_{12}$, see Figure 2. The multiple superexchange interactions that result in this magnetic structure have been described in detail previously[1]. 
The introduction of $\mathrm{Ni}^{2+}$ onto $25 \%$ of the $4 f$ sites reduces the value of the mean ordered moment from 4.61(2) $\mu_{\mathrm{B}}$ to 3.70(2) $\mu_{\mathrm{B}}$, a slightly larger reduction than would be expected if $\mathrm{Ni}^{2+}$, with an ordered moment of $1.8 \mu_{\mathrm{B}}[14]$, simply replaced ordered $\mathrm{Mn}^{2+}$ cations in the solid solution. It is likely that the introduction of $d^{8}$ cations into the existing array of $d^{5}$ cations reduces the effectiveness of the antiferromagnetic superexchange coupling and hence reduces the mean cation moment. It is noteworthy that although the introduction of $25 \%$ $\mathrm{Co}^{2+}$ onto the $4 f$ sites of $\mathrm{CeMn}_{2} \mathrm{Ge}_{4} \mathrm{O}_{12}$ caused the ordered spins to rotate from [001] to a direction in the (001) sheets[1], no such rotation is caused by the introduction of $25 \% \mathrm{Ni}^{2+}$. This emphasises the extent to which the magnetic behaviour of the $\mathrm{CeMn}_{2-\mathrm{x}} \mathrm{Co}_{\mathrm{x}} \mathrm{Ge}_{4} \mathrm{O}_{12}$ solid solution was controlled by the anisotropy of the $\mathrm{Co}^{2+}$ cation.

The curves illustrating $\chi(T)$ and $M(H)$ for $\mathrm{CeCo}_{1.5} \mathrm{Ni}_{0.5} \mathrm{Ge}_{4} \mathrm{O}_{12}$ and $\mathrm{CeCo}_{1.5} \mathrm{Cu}_{0.5} \mathrm{Ge}_{4} \mathrm{O}_{12}$ are very similar in shape, see Figure 5. They indicate that both compounds order antiferromagnetically with Néel temperatures of 4.6 and $7 \mathrm{~K}$, respectively and that the rate of increase of the magnetisation with field increases when $\mathrm{H}>3 \mathrm{kOe}$. Their bulk magnetic properties are thus very similar to those of $\mathrm{CeCo}_{2} \mathrm{Ge}_{4} \mathrm{O}_{12}$ and $\mathrm{CeCo}_{1.5} \mathrm{Mn}_{0.5} \mathrm{Ge}_{4} \mathrm{O}_{12}$, which order at 4.2 and $5.4 \mathrm{~K}$, respectively. We have been able to show by neutron diffraction that the magnetic structure adopted in the absence of an applied field by $\mathrm{CeCo}_{1.5} \mathrm{Cu}_{0.5} \mathrm{Ge}_{4} \mathrm{O}_{12}$ is the same as that found in $\mathrm{CeCo}_{2} \mathrm{Ge}_{4} \mathrm{O}_{12}$ and $\mathrm{CeCo}_{1.5} \mathrm{Mn}_{0.5} \mathrm{Ge}_{4} \mathrm{O}_{12}$, and that the magnetic structures of all three compositions undergo a similar metamagnetic transition in an applied field. Although we do not have neutron diffraction data on $\mathrm{CeCo}_{1.5} \mathrm{Ni}_{0.5} \mathrm{Ge}_{4} \mathrm{O}_{12}$, the magnetometry data lead us to conclude that a similar transition occurs in that compound. Note that the magnetic structure of $\mathrm{CeCo}_{2} \mathrm{Ge}_{4} \mathrm{O}_{12}$ is thus robust against substitution by $\mathrm{Mn}^{2+}$, $\mathrm{Ni}^{2+}$ and $\mathrm{Cu}^{2+}$ at a level of $25 \%$.

The mean ordered magnetic moment at the $4 f$ site of $\mathrm{CeCo}_{1.5} \mathrm{Cu}_{0.5} \mathrm{Ge}_{4} \mathrm{O}_{12}$ in the absence of an applied field is 2.42(3) $\mu_{\mathrm{B}}$ per cation, see Table 7. The ordered magnetic moment of $\mathrm{Cu}^{2+}$ in $\mathrm{La}_{2} \mathrm{CuO}_{4}$ is $\sim 0.5 \mu_{\mathrm{B}}[15]$ and that of $\mathrm{Co}^{2+}$ in $\mathrm{CeCo}_{2} \mathrm{Ge}_{4} \mathrm{O}_{12}$ is $2.58(2) \mu_{\mathrm{B}}$. The moment in the substituted material is thus surprisingly large and it increases to $3.04 \mu_{\mathrm{B}}$ when a field of 30 $\mathrm{kOe}$ is applied. We have previously pointed out that the ordered moment is unusually low in both $\mathrm{CeCo}_{2} \mathrm{Ge}_{4} \mathrm{O}_{12}$ and $\mathrm{ZrCo}_{2} \mathrm{Ge}_{4} \mathrm{O}_{12}$, given that the effective magnetic moment of each in the paramagnetic phase is $5.36 \mu_{\mathrm{B}}$ and an ordered moment in excess of the spin-only value, $3 \mu_{\mathrm{B}}$, would therefore be expected. We suggested that this apparent anomaly might be caused by an orbital contribution to the magnetic moment that is present in the paramagnetic phase but does not participate in the low-temperature ordering. The Curie constant of 
$\mathrm{CeCo}_{1.5} \mathrm{Cu}_{0.5} \mathrm{Ge}_{4} \mathrm{O}_{12}$, see Table 2, is also consistent with the presence of an orbital contribution from $\mathrm{Co}^{2+}$ and it is possible that the observed ordered moment of $\mathrm{CeCo}_{1.5} \mathrm{Cu}_{0.5} \mathrm{Ge}_{4} \mathrm{O}_{12}$ includes a greater orbital component than does that of $\mathrm{CeCo}_{2} \mathrm{Ge}_{4} \mathrm{O}_{12}$ and that the magnitude of the orbital contribution is a function of applied field.

\section{Conclusions}

We have shown that no more than $25 \%$ of the $d$-block cations in $\mathrm{CeMn}_{2} \mathrm{Ge}_{4} \mathrm{O}_{12}$ and $\mathrm{CeCo}_{2} \mathrm{Ge}_{4} \mathrm{O}_{12}$ can be replaced by $\mathrm{Ni}^{2+}$ or $\mathrm{Cu}^{2+}$. The coordination requirements of the $\mathrm{Ce}^{4+}$ cations and the $\mathrm{Ge}_{4} \mathrm{O}_{12}$ groups preclude the introduction of a higher concentration of the relatively small substituents. The introduction of $\mathrm{Ni}^{2+}$ has little effect on the magnetic properties of either $\mathrm{CeMn}_{2} \mathrm{Ge}_{4} \mathrm{O}_{12}$ or $\mathrm{CeCo}_{2} \mathrm{Ge}_{4} \mathrm{O}_{12}$ and $\mathrm{Cu}^{2+}$ has little effect on those of $\mathrm{CeCo}_{2} \mathrm{Ge}_{4} \mathrm{O}_{12}$. Comparison with the results of our earlier study[1] of $\mathrm{CeMn}_{2-\mathrm{x}} \mathrm{Co}_{\mathrm{x}} \mathrm{Ge}_{4} \mathrm{O}_{12}$ leads to the conclusion that the anisotropy associated with the $\mathrm{Co}^{2+}$ cation is able to dictate the magnetic behaviour of these compounds when it is present in concentrations of $25 \%$ or above.

\section{References}

[1] D. Xu, M. Avdeev, P.D. Battle, X.Q. Liu, Inorg. Chem. 56 (2017) 2750-2762.

[2] K. Momma, F. Izumi, Journal of Applied Crystallography 41 (2008) 653-658.

[3] E.O. Wollan, W.C. Koehler, Physical Review 100 (1955) 545-563.

[4] D. Xu, M. Sale, M. Avdeev, C.D. Ling, P.D. Battle, Dalton Trans. 46 (2017) 6921 6933.

[5] C. Taviot-Gueho, P. Leone, P. Palvadeau, J. Rouxel, J. Solid State Chem. 143 (1999) $145-150$.

[6] H.M. Rietveld, Journal of Applied Crystallography 2 (1969) 65 - 71.

[7] A.C. Larson, R.B. von-Dreele General Structure Analysis System (GSAS) Los Alamos National Laboratories LAUR 86-748 1994

[8] B. van Laar, and W. B. Yelon, Journal of Applied Crystallography 17 (1984) 47-54.

[9] M.A. Green, M. Kurmoo, J.K. Stalick, P. Day, Journal of the Chemical SocietyChemical Communications (1994) 1995-1996.

[10] J.M. Perez-Mato, S.V. Gallego, E.S. Tasci, L. Elcoro, G. de la Flor, M.I. Aroyo, Ann. Rev. Mater. Res. 45 (2015) 217-248.

[11] G.J. Redhammer, A. Senyshyn, G. Tippelt, C. Pietzonka, G. Roth, G. Amthauer, Physics and Chemistry of Minerals 37 (2010) 311-332.

[12] S. Sasaki, K. Fujino, Y. Takeuchi, Proceedings of the Japan Academy Series BPhysical and Biological Sciences 55 (1979) 43-48.

[13] P. Zolliker, D.E. Cox, J.B. Parise, E.M. McCarron, W.E. Farneth, Physical Review B 42 (1990) 6332-6341.

[14] H.A. Alperin, J. Phys. Soc. Japan 17 (1962) Suppl. BIII, 12.

[15] D. Vaknin, S.K. Sinha, D.E. Moncton, D.C. Johnston, J.M. Newsam, C.R. Safinya, H.E. King, Physical Review Letters 58 (1987) 2802. 
Table 1 Room-temperature unit-cell parameters of $\mathrm{Ce}_{1.5} M^{\prime}{ }_{0.5} \mathrm{Ge}_{4} \mathrm{O}_{12}\left(M=\mathrm{Mn}, \mathrm{Co} ; M^{\prime}=\right.$ $\mathrm{Ni}, \mathrm{Cu}$ ) derived from X-ray diffraction data

\begin{tabular}{lcccc}
\hline & \multicolumn{2}{c}{$M=\mathrm{Mn}$} & \multicolumn{2}{c}{$M=\mathrm{Co}$} \\
\cline { 2 - 5 } & $M^{\prime}=\mathrm{Ni}$ & $M^{\prime}=\mathrm{Cu}$ & $M^{\prime}=\mathrm{Ni}$ & $M^{\prime}=\mathrm{Cu}$ \\
\hline$a / \AA$ & $9.8087(1)$ & $9.7886(1)$ & $9.7376(2)$ & $9.7324(2)$ \\
$c / \AA$ & $4.8784(1)$ & $4.8715(1)$ & $4.8117(1)$ & $4.8119(1)$ \\
$V / \AA^{3}$ & $469.35(2)$ & $466.77(2)$ & $456.25(2)$ & $455.78(3)$
\end{tabular}

Table 2 Magnetic parameters of $\mathrm{Ce}_{1.5} M^{\prime}{ }_{0.5} \mathrm{Ge}_{4} \mathrm{O}_{12}\left(M=\mathrm{Mn}, \mathrm{Co} ; M^{\prime}=\mathrm{Ni}, \mathrm{Cu}\right)$

\begin{tabular}{llll}
\hline & \multicolumn{2}{c}{$M=\mathrm{Mn}$} & \multicolumn{2}{c}{$M=\mathrm{Co}$} \\
\cline { 2 - 4 } & $M^{\prime}=\mathrm{Ni}$ & $M^{\prime}=\mathrm{Ni}$ & $M^{\prime}=\mathrm{Cu}$ \\
\hline$C / \mathrm{cm}^{3} \mathrm{~K} \mathrm{~mol}^{-1}$ & $7.120(1)$ & $5.977(1)$ & $5.602(1)$ \\
$\theta / \mathrm{K}$ & $-11.49(2)$ & -17.21 & -21.48 \\
$\mu_{\mathrm{eff}}(\mathrm{Ni} / \mathrm{Cu}) / \mu_{\mathrm{B}}{ }^{*}$ & 3.02 & 3.07 & 1.86 \\
$T_{N} / \mathrm{K}$ & 7.0 & 4.6 & 7.0 \\
\hline
\end{tabular}

$*$ calculated using $\mu_{\text {eff }}(\mathrm{Mn})=5.91$ and $\mu_{\text {eff }}(\mathrm{Co})=5.35$. 
Table 3 Structural parameters of $\mathrm{CeMn}_{1.5} \mathrm{Ni}_{0.5} \mathrm{Ge}_{4} \mathrm{O}_{12}$ at room temperature (RT) and $1.6 \mathrm{~K}$ derived from neutron diffraction data.

\begin{tabular}{|c|c|c|c|}
\hline & & \multicolumn{2}{|c|}{ Temperature } \\
\hline & & RT & $1.6 \mathrm{~K}$ \\
\hline $\mathrm{Ce}$ & $U_{\text {iso }} / \AA^{2}$ & $0.0038(7)$ & $0.0029(9)$ \\
\hline $\mathrm{Mn} / \mathrm{Ni}$ & $U_{\mathrm{iso}} / \AA^{2}$ & $0.0176(23)$ & $0.0093(8)$ \\
\hline \multirow[t]{2}{*}{$\mathrm{Ge}$} & $X$ & $0.5242(1)$ & $0.5242(1)$ \\
\hline & $U_{\text {iso }} / \AA^{2}$ & $0.0044(2)$ & $0.0017(3)$ \\
\hline \multirow[t]{3}{*}{$\mathrm{O} 1$} & $X$ & $-0.3701(1)$ & $-0.3697(2)$ \\
\hline & $Z$ & $0.1726(3)$ & $0.1732(3)$ \\
\hline & $U_{\text {iso }} / \AA^{2}$ & $0.0058(4)$ & $0.0017(4)$ \\
\hline \multirow[t]{4}{*}{$\mathrm{O} 2$} & $x$ & $0.1653(1)$ & $0.1651(1)$ \\
\hline & $y$ & $0.0643(1)$ & $0.0645(1)$ \\
\hline & $z$ & $0.2552(2)$ & $0.2560(3)$ \\
\hline & $U_{\text {iso }} / \AA^{2}$ & $0.0068(2)$ & $0.0031(3)$ \\
\hline$a / \AA$ & & $9.8062(1)$ & $9.8016(2)$ \\
\hline$c / \AA$ & & $4.8777(1)$ & $4.8712(1)$ \\
\hline$V / \AA^{3}$ & & $469.05(2)$ & $467.98(2)$ \\
\hline $\mathrm{R}_{\mathrm{wpr}}$ & & $4.48 \%$ & $4.04 \%$ \\
\hline$\chi^{2}$ & & 1.899 & 8.505 \\
\hline
\end{tabular}

Space group $P 4 / n b m$ (No. 125), $\mathrm{Z}=2$

Ce on $2 b(1 / 4,1 / 4,1 / 2) ; \mathrm{Mn} / \mathrm{Ni}$ on $4 f(0,0,1 / 2)$;

Ge on $8 k(x, 1 / 4,0)$; $\mathrm{O} 1$ on $8 m(x,-x, z)$; $\mathrm{O} 2$ on $16 n(x, y, z)$ 
Table 4 Bond lengths ( $⿱$ ) and bond angles (degrees) in $\mathrm{CeMn}_{1.5} \mathrm{Ni}_{0.5} \mathrm{Ge}_{4} \mathrm{O}_{12}$ at room temperature (RT) and $1.6 \mathrm{~K}$ derived from neutron diffraction data

\begin{tabular}{|c|c|c|}
\hline & \multicolumn{2}{|c|}{ Temperature } \\
\hline & RT & $1.6 \mathrm{~K}$ \\
\hline $\mathrm{Ce}-\mathrm{O} 2 \times 8$ & $2.331(1)$ & $2.326(1)$ \\
\hline $\mathrm{Mn} / \mathrm{Ni}-\mathrm{O} 1 \times 2$ & $2.408(1)$ & $2.408(2)$ \\
\hline $\mathrm{Mn} / \mathrm{Ni}-\mathrm{O} 2 \times 4$ & $2.110(1)$ & $2.105(1)$ \\
\hline $\mathrm{O} 2-\mathrm{O} 2{ }^{\prime} *$ & $3.184(2)$ & $3.182(2)$ \\
\hline $\mathrm{O} 2-\mathrm{O} 2 \% *$ & $2.769(2)$ & $2.756(2)$ \\
\hline $\mathrm{Ge}-\mathrm{O} 1 \times 2$ & $1.781(1)$ & $1.780(2)$ \\
\hline $\mathrm{Ge}-\mathrm{O} 2 \times 2$ & $1.730(1)$ & $1.733(2)$ \\
\hline $\mathrm{O} 2-\mathrm{Mn} / \mathrm{Ni}-\mathrm{O} 2$ ' & $97.98(4)$ & $98.22(5)$ \\
\hline $\mathrm{O} 2-\mathrm{Mn} / \mathrm{Ni}-\mathrm{O} 2 "$ & $82.02(4)$ & $81.78(5)$ \\
\hline $\mathrm{O} 1-\mathrm{Mn} / \mathrm{Ni}-\mathrm{O} 2$ ' & $82.70(4)$ & $82.84(5)$ \\
\hline $\mathrm{O} 1-\mathrm{Mn} / \mathrm{Ni}-\mathrm{O} 2 ”$ & $97.30(4)$ & $97.16(5)$ \\
\hline O1-Ge-O1 & $108.76(6)$ & $108.48(8)$ \\
\hline O1-Ge-O2 & $105.63(6)$ & $105.67(8)$ \\
\hline O1-Ge-O2 & $108.34(6)$ & $108.52(8)$ \\
\hline $\mathrm{O} 2-\mathrm{Ge}-\mathrm{O} 2$ & 119.81(6) & $119.81(8)$ \\
\hline
\end{tabular}

* distances within the equatorial plane of the $(\mathrm{Mn} / \mathrm{Ni}) \mathrm{O}_{6}$ octahedra 
Table 5 Structural parameters of $\mathrm{CeCo}_{1.5} \mathrm{Cu}_{0.5} \mathrm{Ge}_{4} \mathrm{O}_{12}{ }^{\dagger}$ at room temperature and $1.6 \mathrm{~K}$ derived from neutron diffraction data

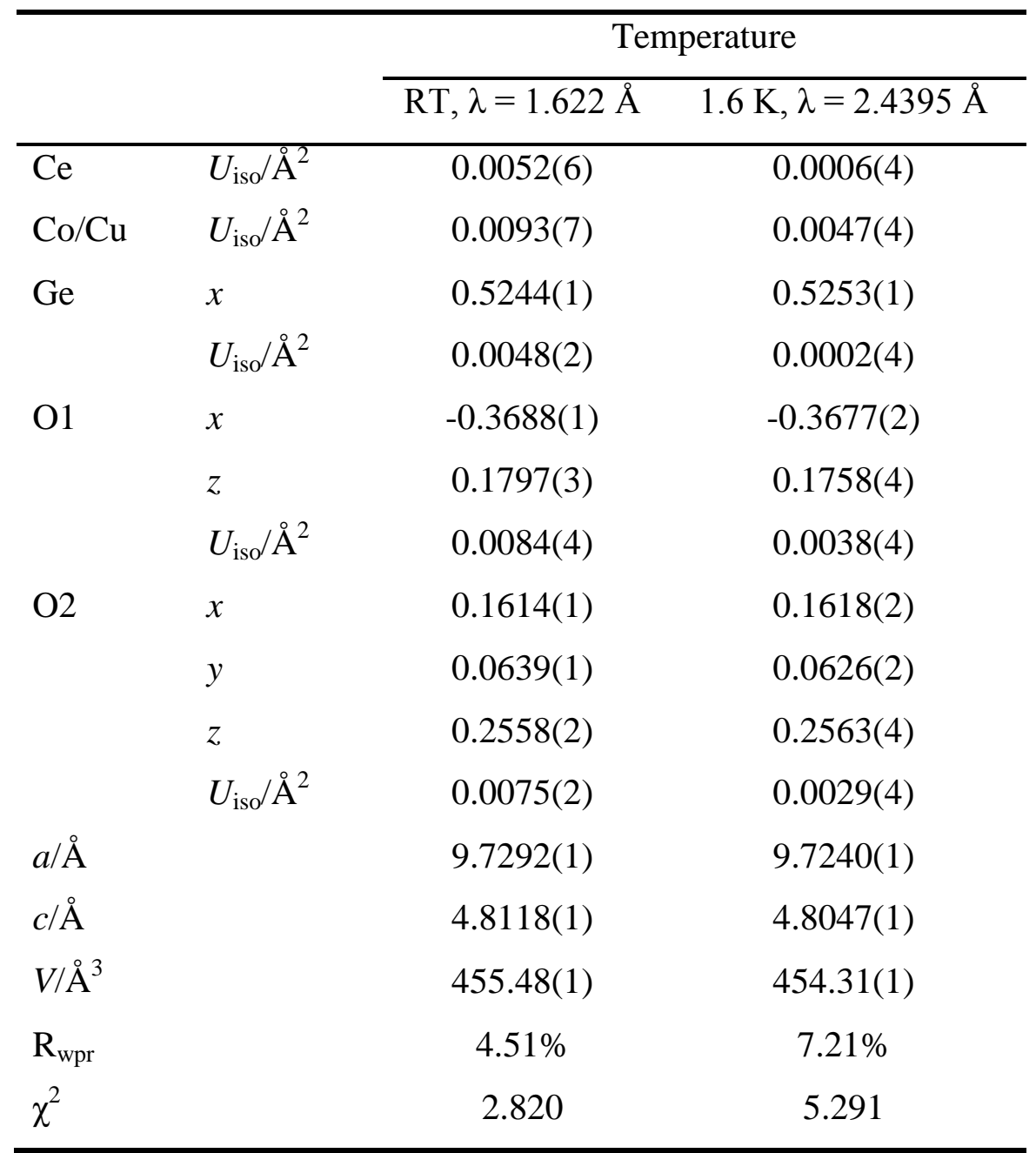

Space group P4/nbm (No. 125), Z $=2$

Ce on $2 b(1 / 4,1 / 4,1 / 2) ; \mathrm{Co} / \mathrm{Cu}$ on $4 f(0,0,1 / 2)$;

Ge on $8 k(x, 1 / 4,0)$; $\mathrm{O} 1$ on $8 m(x,-x, z)$; O2 on $16 n(x, y, z)$

${ }^{\dagger}$ Contains 2.0(1) wt \% $\mathrm{CoGeO}_{3}$ 
Table 6 Bond lengths $(\AA)$ and bond angles (degrees) in $\mathrm{CeCo}_{1.5} \mathrm{Cu}_{0.5} \mathrm{Ge}_{4} \mathrm{O}_{12}$ at $1.6 \mathrm{~K}$ and room temperature (RT) derived from neutron diffraction data

\begin{tabular}{ccc}
\hline & \multicolumn{2}{c}{ Temperature } \\
\cline { 2 - 3 } $\mathrm{Ce}-\mathrm{RT} 2 \times 8=1.622 \AA$ & $1.6 \mathrm{~K}, \lambda=2.4395 \AA$ \\
$\mathrm{Co} / \mathrm{Cu}-\mathrm{O} 1 \times 2$ & $2.324(1)$ & $2.330(2)$ \\
$\mathrm{Co} / \mathrm{Cu}-\mathrm{O} 2 \times 4$ & $2.058(1)$ & $2.383(3)$ \\
$\mathrm{O} 2-\mathrm{O} 2{ }^{*} *$ & $3.101(1)$ & $2.053(2)$ \\
$\mathrm{O} 2-\mathrm{O}{ }^{\prime} *$ & $2.706(2)$ & $3.086(3)$ \\
$\mathrm{Ge}-\mathrm{O} 1 \times 2$ & $1.778(1)$ & $2.710(3)$ \\
$\mathrm{Ge}-\mathrm{O} 2 \times 2$ & $1.731(1)$ & $1.771(2)$ \\
$\mathrm{O} 2-\mathrm{Co} / \mathrm{Cu}-\mathrm{O} 2$ & & $1.727(2)$ \\
$\mathrm{O} 2-\mathrm{Co} / \mathrm{Cu}-\mathrm{O} 2 ”$ & $82.22(6)$ & $97.41(11)$ \\
$\mathrm{O} 1-\mathrm{Co} / \mathrm{Cu}-\mathrm{O} 2$ & $82.96(4)$ & $83.40(7)$ \\
$\mathrm{O} 1-\mathrm{Co} / \mathrm{Cu}-\mathrm{O} 2 ”$ & $97.04(4)$ & $95.60(7)$ \\
$\mathrm{O} 1-\mathrm{Ge}-\mathrm{O} 1$ & $108.48(11)$ & $108.09(18)$ \\
$\mathrm{O} 1-\mathrm{Ge}-\mathrm{O} 2$ & $105.53(5)$ & $105.33(8)$ \\
$\mathrm{O} 1-\mathrm{Ge}-\mathrm{O} 2$ & $108.21(7)$ & $108.48(12)$ \\
$\mathrm{O} 2-\mathrm{Ge}-\mathrm{O} 2$ & $120.46(9)$ & $120.66(17)$ \\
\hline
\end{tabular}

* distances within the equatorial plane of the $(\mathrm{Co} / \mathrm{Cu}) \mathrm{O}_{6}$ octahedra

Table 7 Mean ordered atomic moments $\left(\mu_{\mathrm{B}}\right)$ at the $4 f$ site in $\mathrm{CeCo}_{1.5} \mathrm{Cu}_{0.5} \mathrm{Ge}_{4} \mathrm{O}_{12}$ as a function of applied magnetic field at $1.6 \mathrm{~K}$

\begin{tabular}{lll}
\hline $\mathrm{H} / \mathrm{kOe}$ & 0 & 30 \\
\hline$M_{x}$ & $2.13(3)$ & $2.29(6)$ \\
$M_{y}$ & $1.15(4)$ & $2.00(4)^{\dagger}$ \\
$M$ & $2.42(3)$ & $3.04(5)$ \\
\hline
\end{tabular}

$\uparrow$ the ferromagnetic component 


\section{Figure Captions}

Figure 1 Polyhedral representation of the crystal structure of $\mathrm{CeMn}_{2-\mathrm{x}} \mathrm{Co}_{\mathrm{x}} \mathrm{Ge}_{4} \mathrm{O}_{12}$ viewed along (a) [001] and (b) [100]: green tetrahedra and purple octahedra represent $\mathrm{GeO}_{4}$ and $(\mathrm{Mn} / \mathrm{Co}) \mathrm{O}_{6}$ groups, respectively; blue circles represent $\mathrm{Ce}^{4+}$ cations.

Figure 2 Magnetic structure of $\mathrm{CeMn}_{2} \mathrm{Ge}_{4} \mathrm{O}_{12}$ in zero field. Diamagnetic ions are omitted.

Figure 3 Magnetic structure of $\mathrm{CeCo}_{2} \mathrm{Ge}_{4} \mathrm{O}_{12}$ in zero field. Diamagnetic ions are omitted.

Figure 4 Magnetic structure of $\mathrm{CeCo}_{2} \mathrm{Ge}_{4} \mathrm{O}_{12}$ in $\mathrm{H}=30 \mathrm{kOe}$. Diamagnetic ions are omitted.

Figure 5 Temperature dependence of the dc molar magnetic susceptibility and field dependence of the magnetization at $2 \mathrm{~K}$ of $\mathrm{Ce} M_{1.5} M^{\prime}{ }_{0.5} \mathrm{Ge}_{4} \mathrm{O}_{12}(M=\mathrm{Mn}, \mathrm{Co}$; $\left.M^{\prime}=\mathrm{Ni}, \mathrm{Cu}\right)$. The data points highlighted in red were fitted to the Curie-Weiss law.

Figure 6 Observed (red dots) and calculated (green line) NPD patterns of $\mathrm{CeMn}_{1.5} \mathrm{Ni}_{0.5} \mathrm{Ge}_{4} \mathrm{O}_{12}$ at (a) room temperature and (b) $1.6 \mathrm{~K} ; \lambda=1.622 \AA$. A difference curve (purple line) is shown and reflection positions are marked for the crystal structure and, at $1.6 \mathrm{~K}$, the magnetic structure (upper set).

Figure 7 Observed (red dots) and calculated (green line) NPD patterns of $\mathrm{CeCo}_{1.5} \mathrm{Cu}_{0.5} \mathrm{Ge}_{4} \mathrm{O}_{12}$ at room temperature; $\lambda=1.622 \AA$. A difference curve (purple line) is shown and reflection positions are marked for the crystal structure and the $\mathrm{CeGeO}_{3}$ impurity phase (upper set).

Figure 8 Observed (red dots) and calculated (green line) NPD patterns of $\mathrm{CeCo}_{1.5} \mathrm{Cu}_{0.5} \mathrm{Ge}_{4} \mathrm{O}_{12}$ at $1.6 \mathrm{~K}$ with $\lambda=2.4395 \AA$ in (a) $\mathrm{H}=0 \mathrm{kOe}$ and (b) $\mathrm{H}=$ $30 \mathrm{kOe}$. A difference curve (purple line) is shown and reflection positions are marked for the crystal structure (nuclear and magnetic) and the $\mathrm{CeGeO}_{3}$ impurity phase (nuclear and magnetic). 
(a)

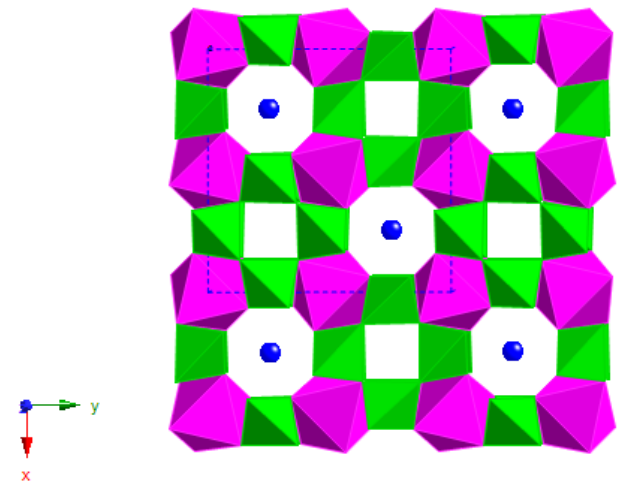

(b)

Figure 1

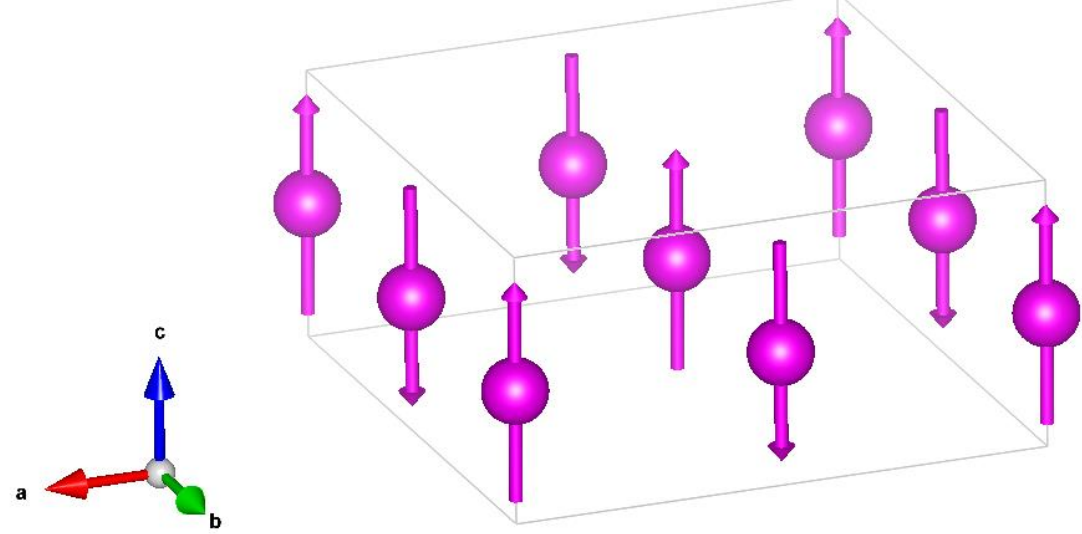

Figure 2 


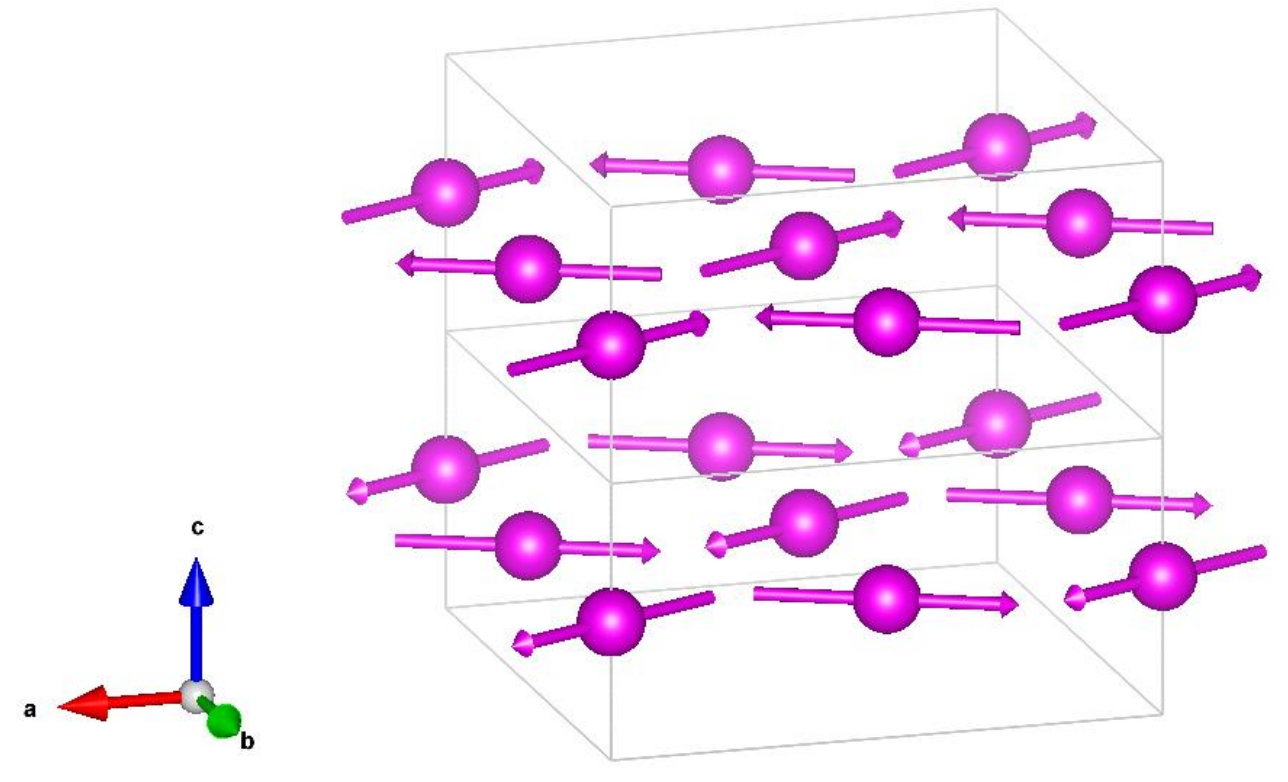

Figure 3

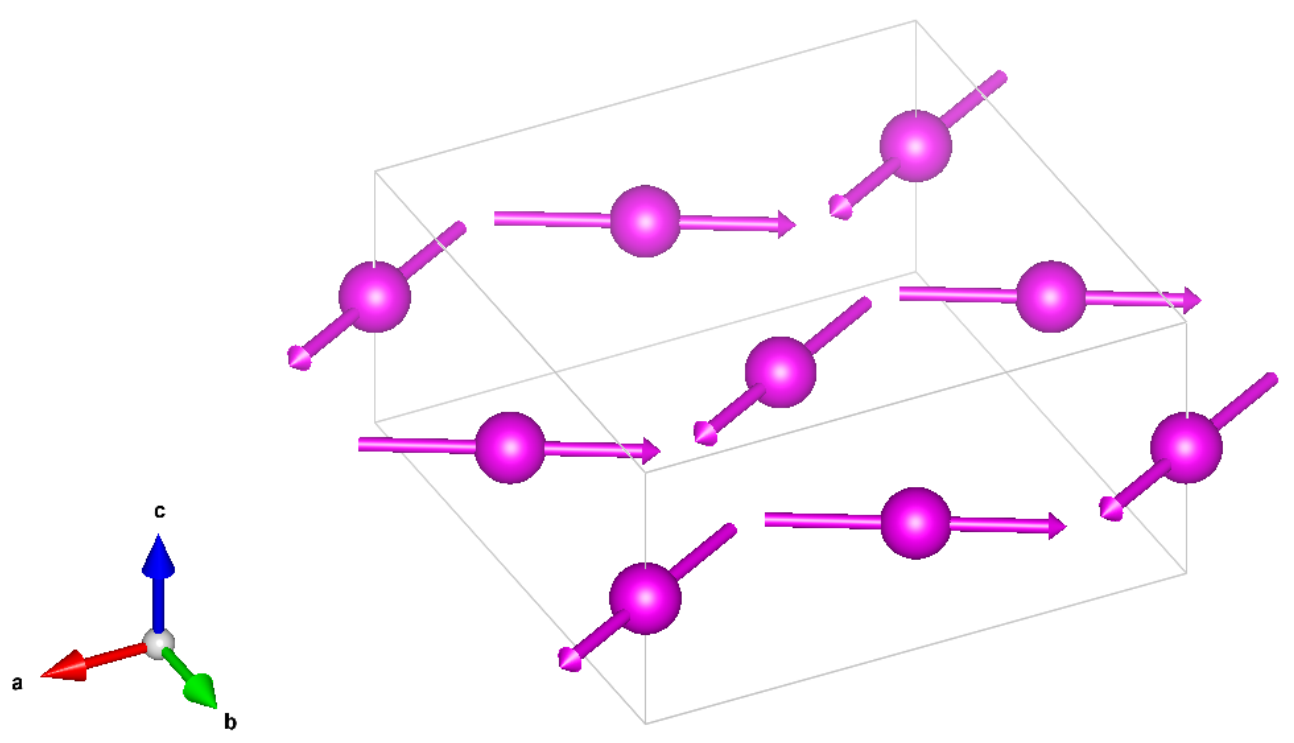

Figure 4 


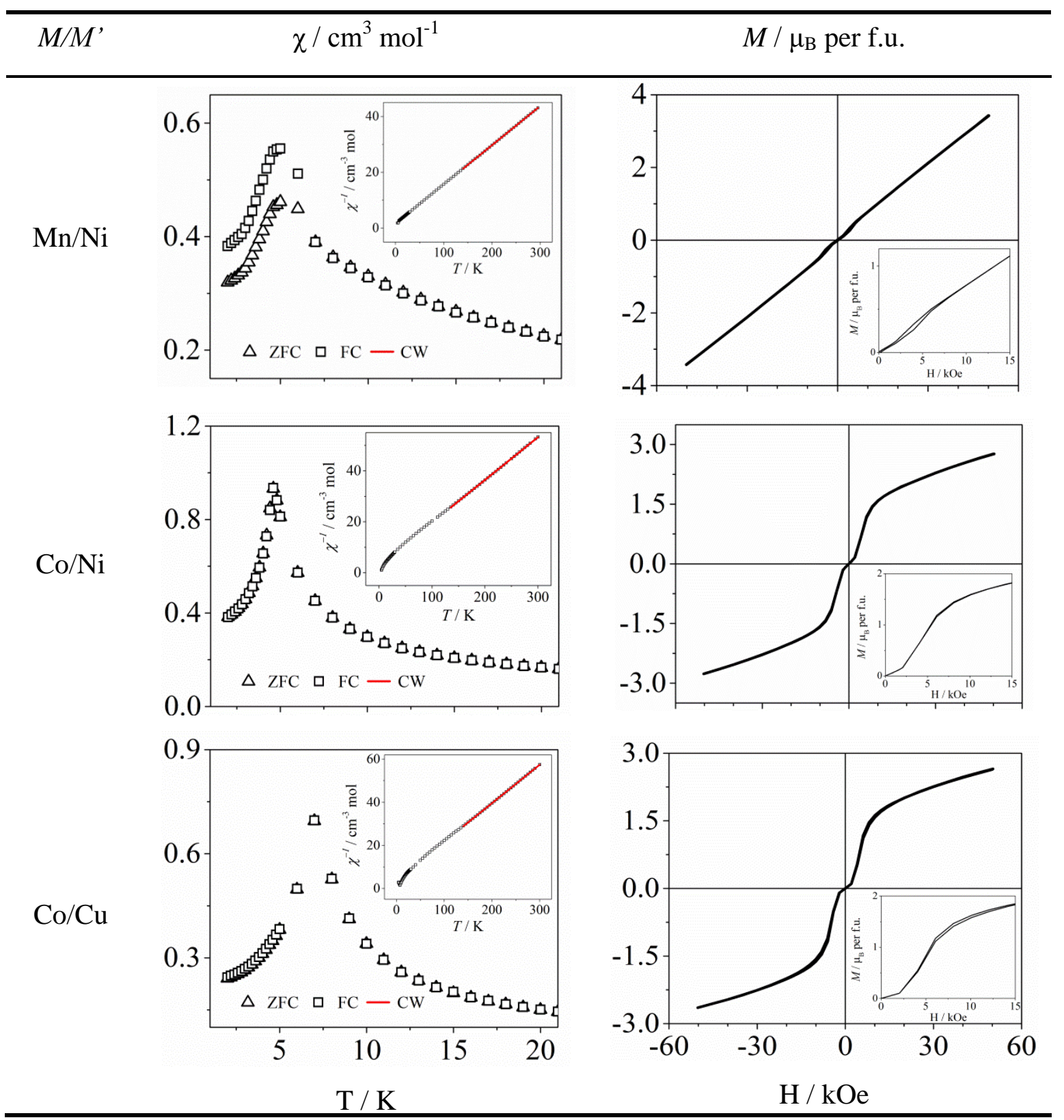

Figure 5 
(a)

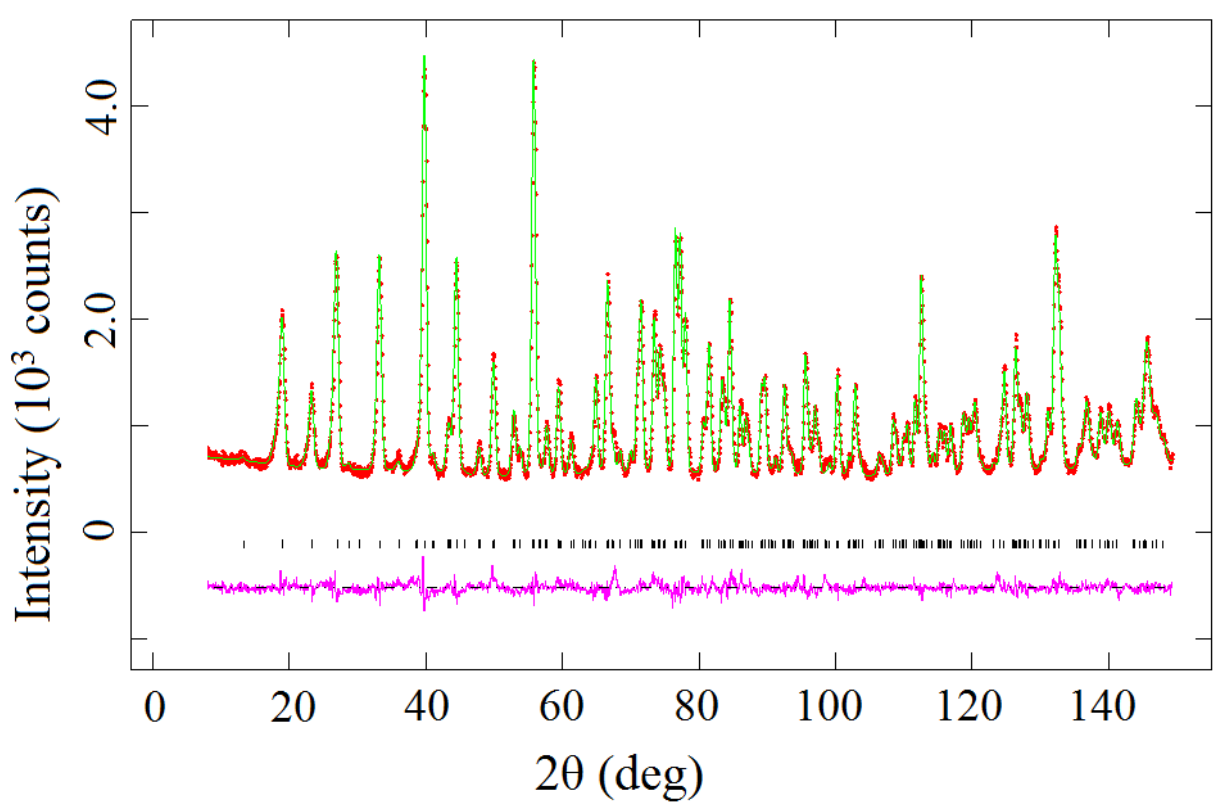

(b)

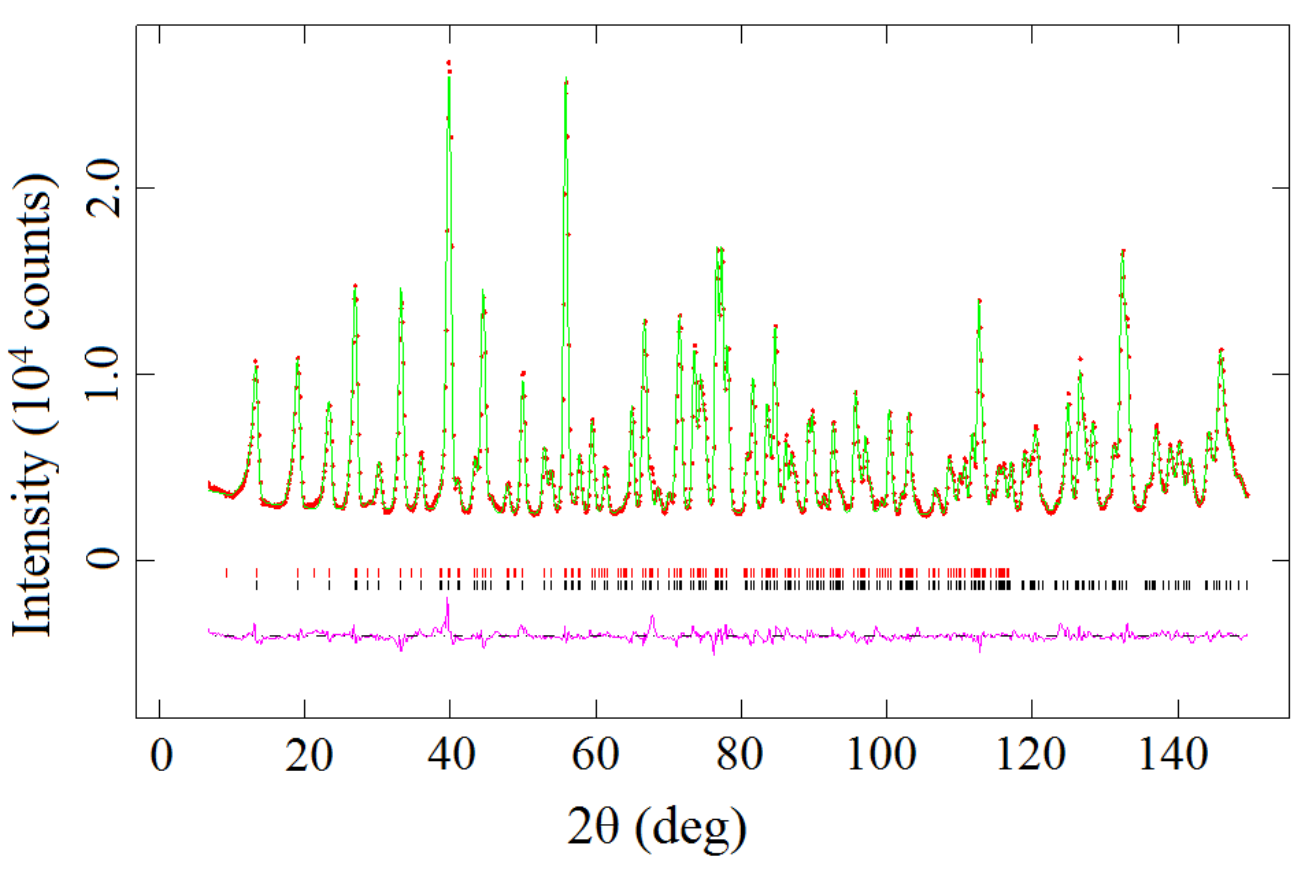

Figure 6 


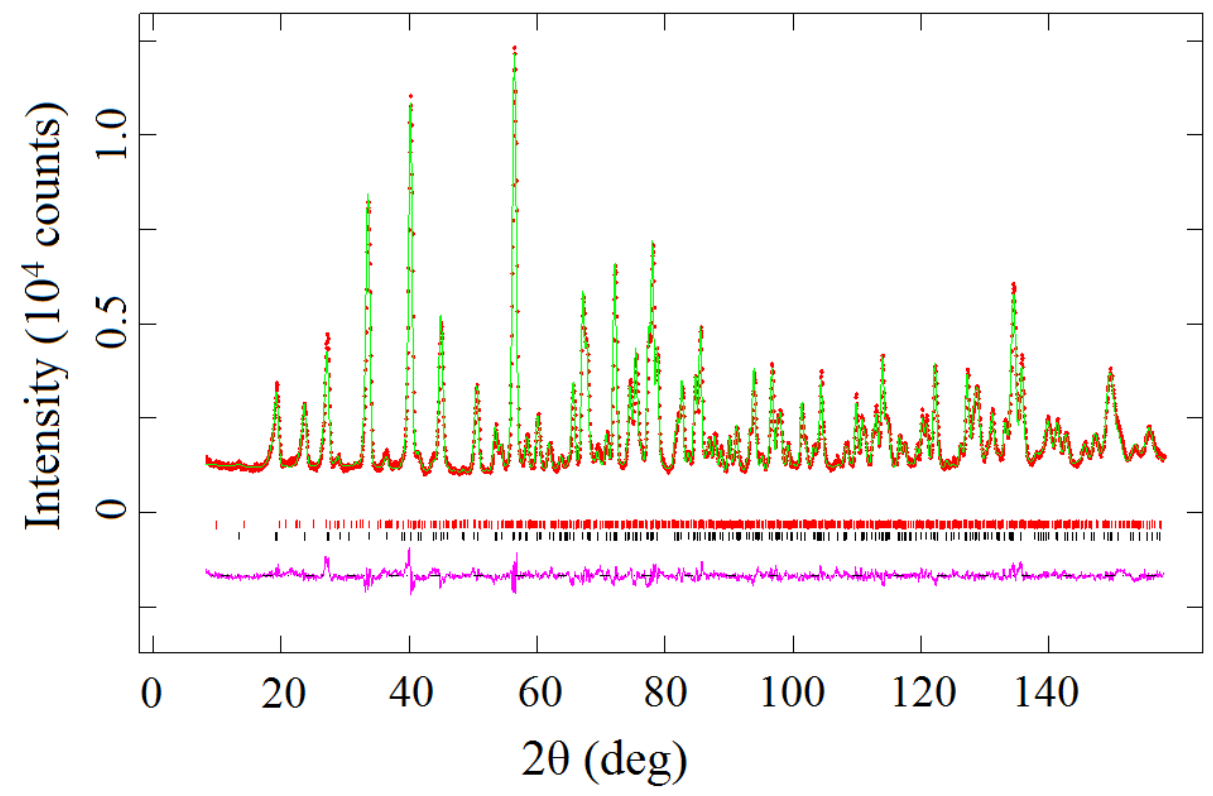

Figure 7 
(a)

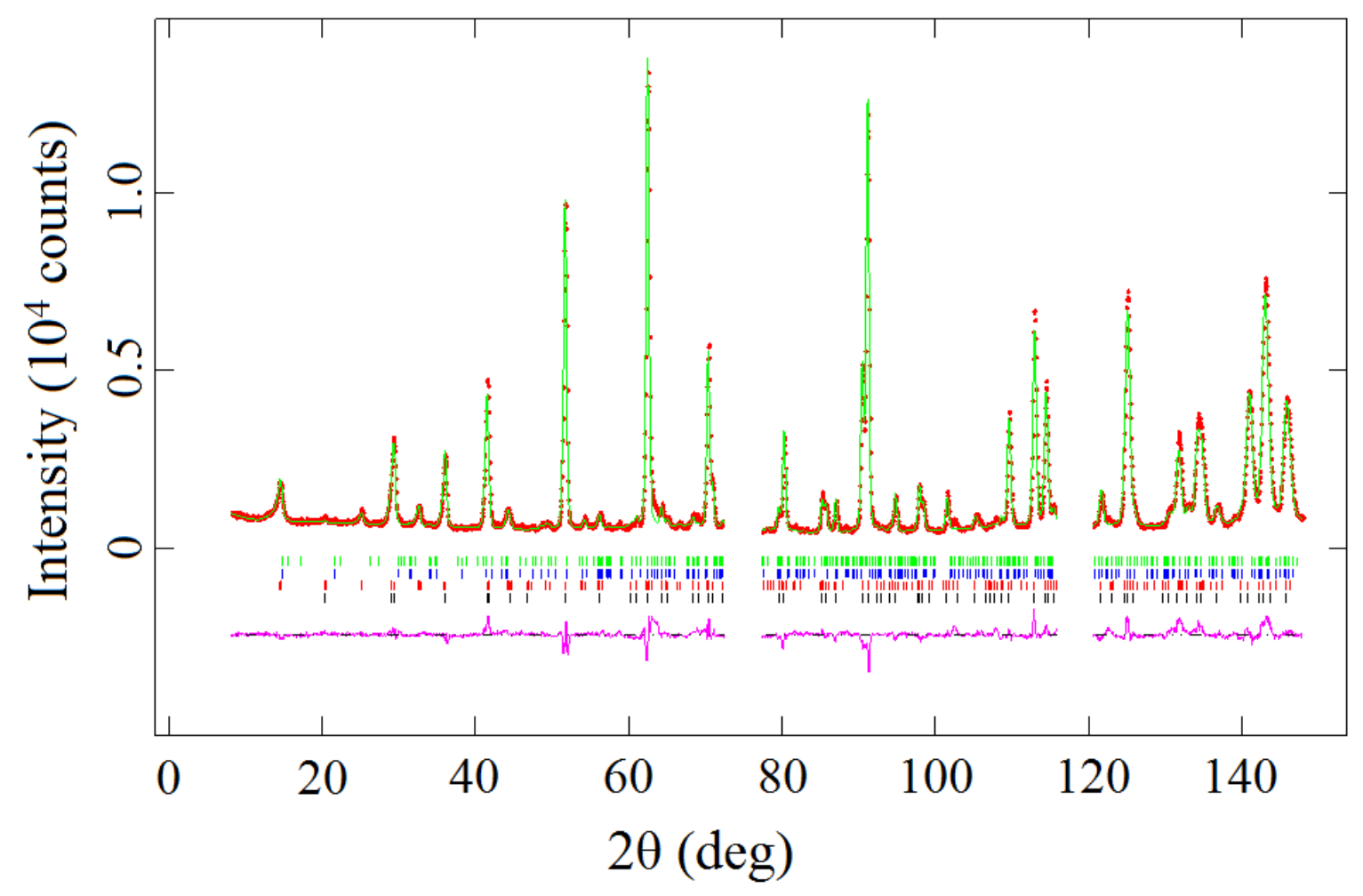

(b)

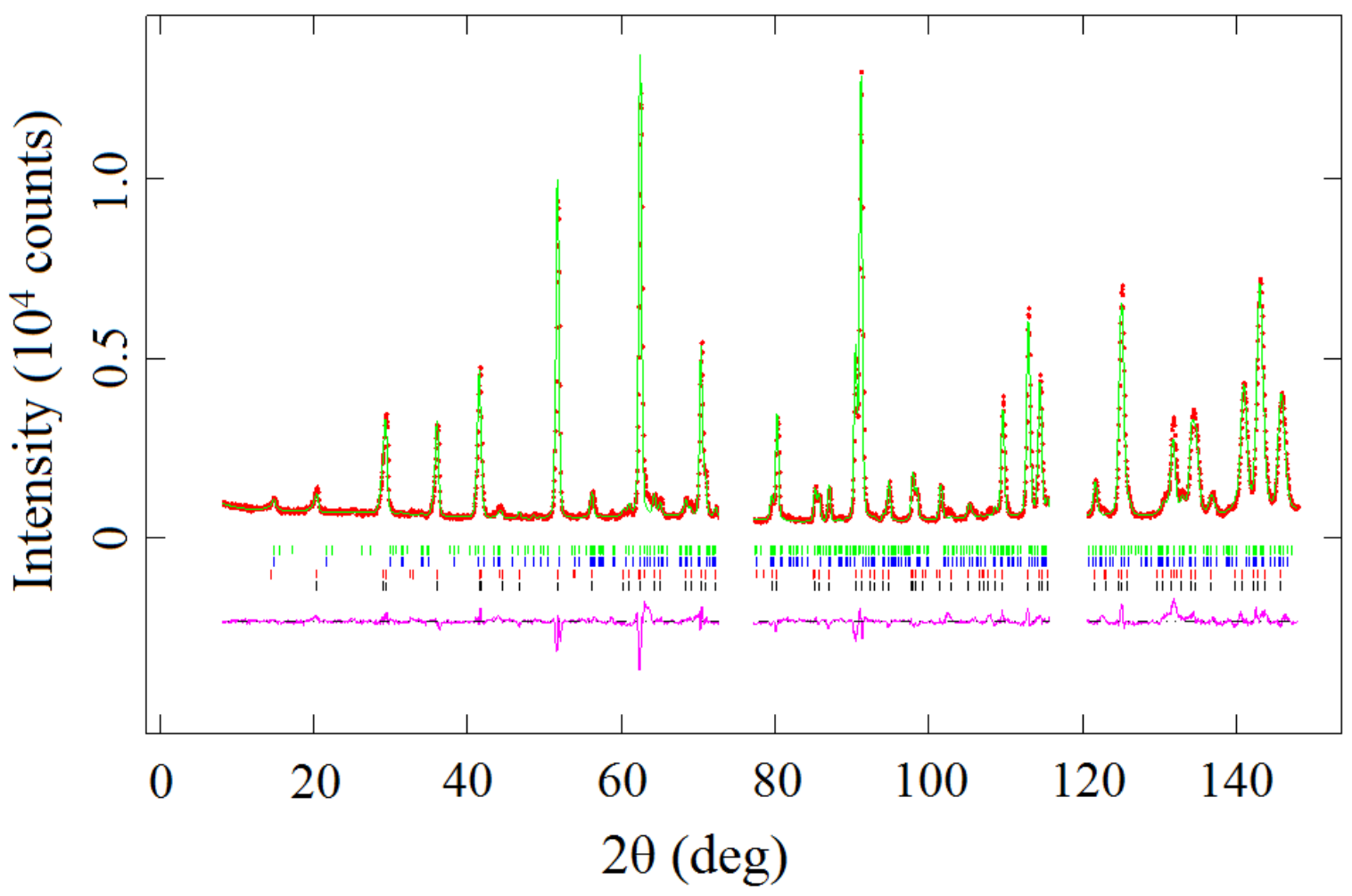

Figure 8 